\title{
Characterisation of Oil Properties from a Niger Delta Crude
}

Ofodile SE, Boisa N, Obunwo CC and Frank OM*

Department of Chemistry, Rivers State University, Port Harcourt, Nigeria

*Corresponding author: Frank OM, Department of Chemistry, Rivers State University, Port Harcourt, Nigeria, Tel: +2347095415002; E-mail: frankolysis80@gmail.com Received: April 09, 2018; Accepted: April 21, 2018; Published: April 28, 2018

Copyright: (c) 2018 Ofodile SE, et al. This is an open-access article distributed under the terms of the Creative Commons Attribution License, which permits unrestricted use, distribution, and reproduction in any medium, provided the original author and source are credited.

\begin{abstract}
The characterization of crude being physical, elemental, compositional and bulk parameter analyses is an investigative approach into the properties of crude oil. This study shows the properties of Afiesere crude oil in the Niger Delta area of Nigeria. The parameters investigated are density, specific gravity, API gravity, vapour pressure, kinematic viscosity, moisture content, gum content, cloud point, pour point, flash point, metallic constituents $(\mathrm{V}, \mathrm{Ni})$, elemental $\left(\mathrm{N}_{2}, \mathrm{O}_{2}, \mathrm{~S}_{2}\right)$ and compositional (aliphatic and heavier) hydrocarbons using ASTM/IP procedural methods. The results show density $\left(0.9440 \mathrm{~g} / \mathrm{cm}^{3}\right)$, specific gravity $(0.9450)$, API gravity $\left(18.2^{\circ}\right)$, vapour pressure $(7 \mathrm{kPa})$, kinematic viscosity $(80.4 \mathrm{cSt})$, moisture $(3175 \mathrm{ppm})$, gum content $(71,000 \mathrm{ppm})$, cloud point $\left(-2^{\circ} \mathrm{C}\right)$, pour point $\left(-10^{\circ} \mathrm{C}\right)$, flash point $\left(95^{\circ} \mathrm{C}\right)$, Vanadium $(0.05 \mathrm{ppm})$, Nickel $(0.39 \mathrm{ppm}), \mathrm{N}_{2}(0.11 \%), \mathrm{O}_{2}(<0.5 \%), \mathrm{S}_{2}(1.25 \%)$, aliphatic hydrocarbons $(0.032-2.804 \%)$, heavier hydrocarbons $(0.210-1.737 \%)$. The outcome of these results can be used effectively to predict the transportation, storage and/or refining of the crude oil being analysed.
\end{abstract}

Keywords: Characterization; Niger delta; Afiesere; Crude oil; Properties

\section{Introduction}

Crude oil is a naturally occurring flammable liquid consisting of a complex of hydrocarbons and heteroatomic organic compounds of various molecular weights [1]. Crude oil exhibits wide variations in composition and properties and these occur not only in crude oil from different fields but also in oil taken from different production depths in the same well [2]. According to history, physical properties like boiling point, viscosity, odour and density (specific gravity) have been used to describe oils; however, because of the molecular complexity of crude oil and bitumen, there is more to analysis identification and characterization than the four properties mentioned above would indicate [2]. The mixture of hydrocarbon is highly complex and elemental analysis of petroleum shows mainly carbon and hydrogen, smaller amounts of nitrogen, oxygen and sulphur as well as trace metals like vanadium, nickel, etc. the refiner is concerned with methods of analysis that would provide information concrete enough to assess the potential quality of the oil, supply preliminary engineering data and indicate if any difficulty would arise in handling, transporting and/or refining crude oil and its products [2]. The end product of crude oil analysis is a series of data that allows the production analyst/ chemist to specify the character and quality of the material being analysed or investigated. Therefore, a series of specifications are determined for crude oil and its products [2].

Worthy of note is the interest of the refiner, marketer and consumer to make sure that the specifications are efficient. The efficiency of the specifications should be able to predict the feedstock behavior and product quality, measure independent properties and with adequate precision as well as render rapid response to refinery and laboratory demands [2]. Hence, crude oil characterization (analysis) is a complex task that needs a multidimensional approach and an explanation of the data obtained needs adequate interpretation. There are different analyses carried out on heavy oil including organic, chemical and elemental characterization. The characterization of heavy oil gives a valuable and detailed insight on the best method of production, cost of refining, environmental impact and the specification regarding the upgrading of heavy conventional oil $[3,4]$. The aim of the research work is to investigate the characterization of crude oil properties from Afiesere oil field and correlate the findings to the quality of the crude in terms of transporting, storing and/or refining of the crude oil.

\section{Materials and Methods}

\section{Description of study area}

Afiesere Oil Field is located at Afiesere community in Ethiope Local government area of Delta State, Nigeria on OML 30 of the NPDC FIELD as shown in the map in Figure 1. The licence covers 1,095 sq. $\mathrm{km}$ and the field was discovered between 1961 to 1966.

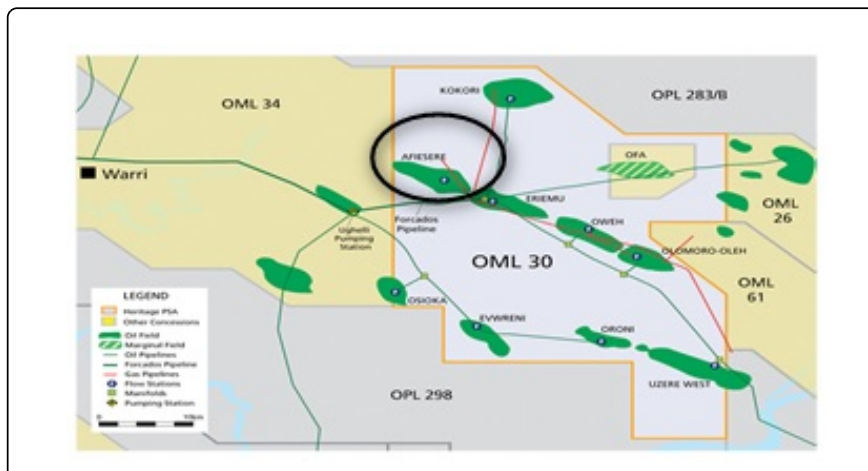

Figure 1: Map of OML 30 showing sample location circled in black.

\section{Sample collection and analyses}

The crude oil sample was collected from the Research \& Development Division of the Nigerian National Petroleum 
Corporation (NNPC). The analyses were carried out at the Water/oil Laboratory of the Eleme Petrochemicals Company Limited, Rivers State and Laser Engineering Laboratory, Port Harcourt. The characterization of the crude oil was done by analysing the physical properties as well as elemental by using modified ASTM/IP Methods. Colour /appearance; Density, specific gravity, API Gravity; Moisture content (IP $831 \mathrm{KF}$ Coulometer); Gum content; Cloud point; Pour point; Flash point; Kinematic and Dynamic viscosities; Reid vapour pressure; Metallic constituents (Operational Manual of Perkin Elmer AAnalyst 200 model) and compositional analysis (GC-FID) [5-12].

\section{Results and Discussion}

The crude oil analysis results are presented in Tables 1-3. The specific gravity values of petroleum products are close to density values and ranges from about $0.80-0.88$ for light crude oils to about $0.94-0.98$ for heavy oils and about 1.00-1.03 for bitumen [2]. The crude being studied falls under the group of heavy oil (Table 1). Earlier, petroleum refining companies, used density and specific gravity data to indicate crude oil quality and correlate it with the aromatic character and saturate (paraffin and naphthene) character that the specific gravity is highest for aromatics and lowest for saturates. The reverse of this analogy is the API gravity. The API gravity of the Afiesere crude oil (Table 1) which is $18.2^{\circ}\left(\leq 20^{\circ}\right)$ implied that, it contains a lesser proportion of lower boiling fractions and higher amounts of the higher boiling asphaltic constituents. This crude oil is heavy crude oil because it does not flow easily and its density /specific gravity are higher than that of light crude oil. Heavy oil is asphaltic (contain asphaltenes and resins). According to Dusseault et al., this type of crude is heavy, dense and viscous due to the high ratio of aromatics and naphthenes to paraffins and high amounts of nitrogen, sulphur, oxygen and heavy metals. The kinematic and dynamic viscosities have particular role in assessing the producibility of a reservoir (rate and amount of oil production from a reservoir) as well as determining the amount of diluent that will permit pipeline transportation of the crude oil i.e., it is used in calculating the flow of liquids through nozzles, orifices and pipelines. The kinematic viscosity of petroleum products is important for flow of fuel through pipelines, injection nozzles and lubricants for bearings, gears, compressor cylinders and hydraulic equipment. Also, for designing proper temperature ranges for the proper operation of the fuel in burners. The lower the viscosity of a fluid, the more easily it flows. Like density, viscosity is affected by temperature. As temperature decreases, viscosity increases. "Thin" liquids, like water or gasoline, have low viscosities; "thick" liquids, like Lubricating oils have higher viscosities. Fuels outside the required range may cause power loss or improper atomization of the fuel in a diesel engine. Lubrications assist in removing the frictional forces between two moving bodies. Moisture (water) can easily find its way into crude oil and its products (fuels) as a result of breathing in moisture laden air in storage facilities. When sudden drop in atmospheric temperature takes place, condensation of moisture occurs. Also, leakages of rain into fuel transportation and storage facilities; leakages of water during shipment of tanker. The presence of water accumulated in tanks used for storage and handling can cause contamination (adverse effect on product quality). The moisture content present in crude oil can also lead to difficulties in refining operations for instance; it corrodes equipment and blocks heat exchangers. Cloud point helps to determine the temperature at which paraffin crystals will begin to block fuel filters and lines and cause starting and stalling problems for diesel engines. The significance of cloud point is that, under low-temperature conditions, paraffinic constituents of a fuel may be precipitated as a wax. The wax settles out and blocks the fuel system lines and filters causing malfunctioning of the engine. Cloud point is one of the main guides to evaluate the wax precipitation of a fluid. Oil products are mixtures of many different components, and those properties of oil products which restrict their usability are often dependent on the properties of the individual components. The pour point of oil indicates the lowest temperature at which oil may be used in some applications. High pour points usually occur in oil that has significant paraffin content. Paraffin (or waxes) will start to precipitate as the temperature decreases. As some point, the precipitate accumulates to the point where the fluids can no longer flow. The lower the pour point, the more useful the oil is in cold temperatures. Afiesere crude oil has very minute percentage of paraffin (Table 1 and Figures $2 \mathrm{a}$ and $2 \mathrm{~b}$ ).

\begin{tabular}{|l|l|l|l|}
\hline S/NO. & Parameter & Unit & Result \\
\hline 1 & Appearance/colour & - & Dark brownish liquid \\
\hline 2 & Density@15 ${ }^{\circ} \mathrm{C}$ & $\mathrm{g} / \mathrm{cm}^{3}$ & 0.944 \\
\hline 3 & Specific gravity@60F & - & 0.945 \\
\hline 4 & API gravity & $\circ$ & 18.2 \\
\hline 5 & Reid vapour pressure & $\mathrm{kPa}$ & 7 \\
\hline 6 & Kinematic viscosity & $\mathrm{CSt}$ & 80.4 \\
\hline 7 & Dynamic viscosity & - & 75.9 \\
\hline 8 & Moisture & $\mathrm{ppm}$ & 3175 \\
\hline 9 & Gum content & $\mathrm{mg} / 100 \mathrm{ml}$ & 71,000 \\
\hline 10 & Cloud point & ${ }^{\circ} \mathrm{C}$ & -2 \\
\hline 11 & Pour point & ${ }^{\circ} \mathrm{C}$ & -10 \\
\hline 12 & Flash point & ${ }^{\circ} \mathrm{C}$ & 95 \\
\hline
\end{tabular}

Table 1: Physical and chemical characteristics of the crude oil.

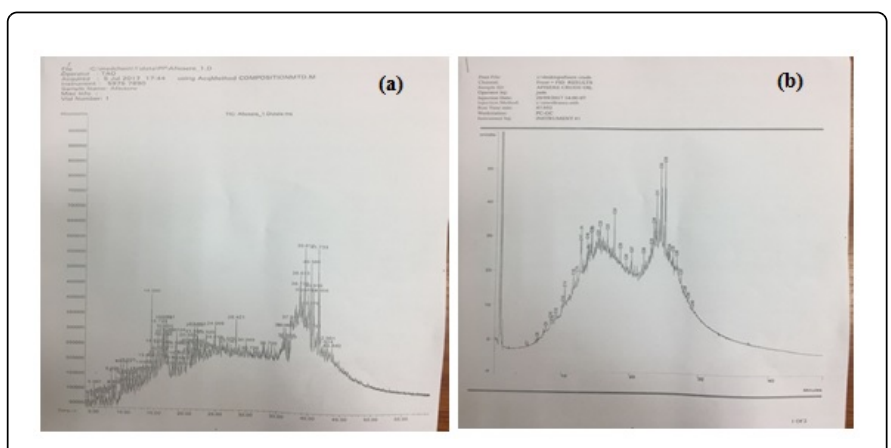

Figure 2: (a) GC Chromatogram of Afiesere crude showing heaviers (b) GC Chromatogram of Afiesere crude showing $\mathrm{C}_{1}$ to $\mathrm{C}_{40}$.

The flash point provides a simple convenient index for assessing the flammability of a wide variety of materials. The flash point is often used as one descriptive characteristic of liquid fuel, but it is used to describe liquids that are not used intentionally as fuel. The flash point is just one flammability characteristics that is used to assess the hazardous nature of a material. Too low a flash point will cause fuel to be a fire hazard, subjecting to flashing, and possible continued ignition and explosion. A low flash point may indicate contamination by more 
Page 3 of 7

volatile and explosive fuel such as gasoline. The values from flash point test can affect how the fluid may be shipped, stored and discarded. Flash point is used by manufacturers and marketers of petroleum products to detect contamination e.g., an abnormally low flash point on a sample of kerosene may indicate gasoline contamination. The flash point is also an aid in establishing the identity of a petroleum product. Another related flammability property of a fluid is its autoignition temperature. This is much higher than the flash point and it represents the temperature at which the sample will ignite from only the heat being applied and no external source of ignition. Vapour pressure is an important physical property of volatile liquids. It is the pressure that a vapour exerts on its surroundings. For volatile petroleum products, vapour pressure is used as an indirect measure of evaporation rate. High vapor pressures and a low distillation temperature for $10 \%$ evaporated both help cold starting. Under hotoperating conditions, high vapor pressure also contributes to vapor lock and increases vapor formation in fuel tanks. In cold weather, a gasoline that is not volatile enough may cause hard starting and poor warm-up. In the winter months, for example, your vehicle's engine is extremely cold before startup, and the gasoline must have a high enough volatility to be able to vaporize easily in a cold engine (Table 2).

\begin{tabular}{|l|l|l|l|l|}
\hline S/no. & Parameter & Symbol & Unit & Result \\
\hline 1 & Nickel & $\mathrm{Ni}$ & $\mathrm{ppm}$ & 0.393 \\
\hline 2 & Vanadium & $\mathrm{V}$ & $\mathrm{ppm}$ & 0.052 \\
\hline 3 & Nitrogen & $\mathrm{N}_{2}$ & $\%$ & 0.111 \\
\hline 4 & Oxygen & $\mathrm{O}_{2}$ & $\%$ & $<0.5$ \\
\hline 5 & Sulphur & $\mathrm{S}$ & $\mathrm{ppm}$ & 1.253 \\
\hline
\end{tabular}

Table 2: Metallic and Elemental constituents of the crude oil.

\section{Metallic constituents of the crude oil}

Metallic trace components such as nickel, vanadium, lead and arsenic have an adverse effect on refining or processing operation. These metals are catalyst poisons, and some of them do additional harm. For example, vanadium compounds damage turbine blades and refractory furnaces but from Table 1, vanadium, Nickel, nitrogen, oxygen and sulphur in the analyzed crude were far below the specification as given by Speight et al., Vanadium 50-250 ppm; Nickel 20-100 ppm; Nitrogen 0.1-2.0\%; Oxygen $0.05-1.5 \%$ and Sulphur $0.05-6.0 \%$, thereby making the Afiesere crude one of the Nigerian crude that has minute quantities of metals and heteroatoms. The metallic and elemental constituents are found in every crude oil and hence, their concentrations must be reduced to enable the conversion of the crude oil to transportation fuel. The essence is that, if sulphur and nitrogen are present in the final fuel during combustion, sulphur oxides $\left(\mathrm{SO}_{\mathrm{x}}\right)$ and nitrogen oxides $\left(\mathrm{NO}_{\mathrm{x}}\right)$ may be formed respectively [13]. Since numerous laboratory techniques are available to analyse a crude oil for metallic contaminants, the one used is a matter of individual preference or availability of analytical tools. However, metallic contaminants are often determined using the Atomic Absorption method.

\section{Aliphatic components present in the crude oil}

The components present in the crude oil indicated a very low paraffinic nature (lighters), higher amounts of heaviers and about 120 carbon atoms (Table 3, Figures $2 \mathrm{a}$ and $2 \mathrm{~b}$ ). This is in line with that heavy crude oil has a higher percentage of compounds with over 60 carbons atoms and hence a high boiling point and molecular weight. $n \mathrm{C}_{7}$ and $n \mathrm{C}_{8}$ were the least $\mathrm{n}$-alkane hydrocarbon obtained on the chromatogram with no traces of $n \mathrm{C}_{5}$ and $n \mathrm{C}_{6}$ on it [14-19].

\begin{tabular}{|c|c|c|c|c|}
\hline S/no. & Parameter & Symbol & $\begin{array}{l}\text { Raw } \text { Data } \\
(\%)\end{array}$ & $\begin{array}{l}\text { Normalized Result } \\
\text { (\%) }\end{array}$ \\
\hline 1 & n-heptane & $\mathrm{C}_{7}$ & 0.059 & 0.032 \\
\hline 2 & n-octane & $\mathrm{C}_{8}$ & 0.205 & 0.11 \\
\hline 3 & n-nonane & $\mathrm{C}_{9}$ & 1.501 & 0.809 \\
\hline 4 & n-decane & $\mathrm{C}_{10}$ & 2.452 & 1.322 \\
\hline 5 & n-undecane & $\mathrm{C}_{11}$ & 1.164 & 0.627 \\
\hline 6 & n-dodecane & $\mathrm{C}_{12}$ & 1.991 & 1.073 \\
\hline 7 & $\mathrm{n}$-tridecane & $\mathrm{C}_{13}$ & 1.43 & 0.771 \\
\hline 8 & n-tetradecane & $\mathrm{C}_{14}$ & 2.936 & 1.583 \\
\hline 9 & $\mathrm{n}$-pentadecane & $\mathrm{C}_{15}$ & 3.806 & 2.051 \\
\hline 10 & n-hexadecane (cetane) & $\mathrm{C}_{16}$ & 3.793 & 2.044 \\
\hline 11 & n-heptadecane & $\mathrm{C}_{17}$ & 3.41 & 1.838 \\
\hline 12 & Pristane & $\operatorname{Pr}$ & 3.452 & 1.861 \\
\hline 13 & n-octadecane & $\mathrm{C}_{18}$ & 1.047 & 0.564 \\
\hline 14 & Phytane & $\mathrm{Ph}$ & 1.185 & 0.639 \\
\hline
\end{tabular}


Citation: Ofodile SE, Boisa N, Obunwo CC, Frank OM (2018) Characterisation of Oil Properties from a Niger Delta Crude. J Environ Anal Toxicol 8: 563. doi:10.4172/2161-0525.1000563

Page 4 of 7

\begin{tabular}{|c|c|c|c|c|}
\hline 15 & n-nonadecane & $\mathrm{C}_{19}$ & 2.479 & 1.336 \\
\hline 16 & n-icosane (eicosane) & $\mathrm{C}_{20}$ & 4.595 & 2.477 \\
\hline 17 & n-henicosane & $\mathrm{C}_{21}$ & 4.54 & 2.447 \\
\hline 18 & n-docosane & $\mathrm{C}_{22}$ & 3.353 & 1.807 \\
\hline 19 & n-tricosane & $\mathrm{C}_{23}$ & 3.138 & 1.691 \\
\hline 20 & n-tetracosane & $\mathrm{C}_{24}$ & 4.466 & 2.407 \\
\hline 21 & n-pentacosane & $\mathrm{C}_{25}$ & 2.633 & 1.419 \\
\hline 22 & n-hexacosane (cerane) & $\mathrm{C}_{26}$ & 2.079 & 1.121 \\
\hline 23 & n-heptacosane & $\mathrm{C}_{27}$ & 3.174 & 1.711 \\
\hline 24 & n-octacosane & $\mathrm{C}_{28}$ & 2.573 & 1.387 \\
\hline 25 & n-nonacosane & $\mathrm{C}_{29}$ & 3.374 & 1.819 \\
\hline 26 & $\mathrm{n}$-triacontane & $\mathrm{C}_{30}$ & 4.826 & 2.601 \\
\hline 27 & n-hentriacontane & $\mathrm{C}_{31}$ & 5.168 & 2.786 \\
\hline 28 & n-dotriacontane & $\mathrm{C}_{32}$ & 5.203 & 2.804 \\
\hline 29 & $\mathrm{n}$-tritriacontane & $\mathrm{C}_{33}$ & 4.616 & 2.488 \\
\hline 30 & n-tetratriacontane & $\mathrm{C}_{34}$ & 2.252 & 1.214 \\
\hline 31 & n-pentatriacontane & $\mathrm{C}_{35}$ & 2.753 & 1.484 \\
\hline 32 & n-hexatriacontane & $\mathrm{C}_{36}$ & 3.787 & 2.041 \\
\hline 33 & n-heptatriacontane & $\mathrm{C}_{37}$ & 3.019 & 1.627 \\
\hline 34 & n-octatriacontane & $\mathrm{C}_{38}$ & 1.36 & 0.733 \\
\hline 35 & n-nonatriacontane & $\mathrm{C}_{39}$ & 1.532 & 0.826 \\
\hline 36 & n-tetracontane & $\mathrm{C}_{40}$ & 0.652 & 0.351 \\
\hline 37 & cyclohexane & & 0.513 & 0.277 \\
\hline 38 & 1,1'-methylene bis-cyclohexane & & 0.39 & 0.21 \\
\hline 39 & 9,12 -octadecadienoic acid $(\mathrm{z}, \mathrm{z})$ - $2 \mathrm{H}$-inden-2-one & & 0.916 & 0.494 \\
\hline 40 & 5-eicosyne & & 0.535 & 0.288 \\
\hline 41 & Trans, cis-1,9-dimethylspiro[4.5] decane & & 0.452 & 0.244 \\
\hline 42 & Isocamphane cyclohexane & & 0.446 & 0.24 \\
\hline 43 & Iridomyrmecin & & 0 & 0 \\
\hline 44 & Bicycle [2.2.1] heptane,2,2,3-trimethyl-endo-amorphane-B & & 0.613 & 0.33 \\
\hline 45 & Naphthalene & & 0.71 & 0.383 \\
\hline 46 & Adamantane & & 0.564 & 0.304 \\
\hline 47 & Tricycle [3.3.1.13.7] decane & & 1.16 & 0.625 \\
\hline 48 & Bicycle [4.1.0] heptane & & 0.509 & 0.274 \\
\hline 49 & Adamantane, 1,3-dimethyl adamantane & & 0.554 & 0.299 \\
\hline 50 & Bicycle [4.1.0] heptane, 3-methyl naphthalene & & 2.216 & 1.194 \\
\hline
\end{tabular}


Citation: Ofodile SE, Boisa N, Obunwo CC, Frank OM (2018) Characterisation of Oil Properties from a Niger Delta Crude. J Environ Anal Toxicol 8: 563. doi:10.4172/2161-0525.1000563

Page 5 of 7

\begin{tabular}{|c|c|c|c|}
\hline 51 & 3,9-epoxy-p-mentha-1,8(10)-diene benzenemethanol & 1.117 & 0.602 \\
\hline 52 & Adamantine,1,3-dimethyl-tricyclo[4.3.1.13,8] undecane & 0.755 & 0.407 \\
\hline 53 & Trans,cis-1,8-dimethylspiro[4.5] decane & 1.069 & 0.576 \\
\hline 54 & 1-(2-cyanoethyl)-2-ethyl-4-methylimidazole & 0.406 & 0.219 \\
\hline 55 & Trans,trans-1,10-dimethylspiro[4.5]decane & 1.073 & 0.578 \\
\hline 56 & Adamantine,1,3-dimethyl-1H-Indene & 1.098 & 0.592 \\
\hline 57 & Benzoic acid & 0 & 0 \\
\hline 58 & Bicycle[2.2.1]heptane & 0 & 0 \\
\hline 59 & Trans,trans-1,8-dimethylspiro[4.5]decane & 0 & 0 \\
\hline 60 & 3-dodecyne & 0.392 & 0.211 \\
\hline 61 & 2H-benzocyclohepten-2-one & 0.92 & 0.496 \\
\hline 62 & Muurolane-A & 0.428 & 0.231 \\
\hline 63 & Cis,cis-2,10-dimethylspiro[5.5] undecane & 0.589 & 0.317 \\
\hline 64 & Cis,trans-2,9-dimethylspiro[5.5]undecane & 0.75 & 0.404 \\
\hline 65 & Bicycle[3.1.1] heptane-2-carboxalde & 0.677 & 0.365 \\
\hline 66 & Neopentylidene cyclohexane & 0.655 & 0.353 \\
\hline 67 & (4R@,5R@,9S@)-5,9-dimethylspiro[3.5]nonan-1-one & 0.853 & 0.46 \\
\hline 68 & 3-dodecyne cyclohexane & 0.404 & 0.218 \\
\hline 69 & 3-cyclohexane-1-carboxaldehyde & 1.874 & 1.01 \\
\hline 70 & cyclopentane & 0 & 0 \\
\hline 71 & Decahydro-4,4,8,9,10-pentamethylnaphthalene bicyclo [2.2.1] heptane & 3.222 & 1.737 \\
\hline 72 & Decahydro-4,4,8,9,10-pentamethylnaphthalene benzene acetonitrile & 1.028 & 0.554 \\
\hline 73 & Isocamphane 3-cyclohexene-1-carboxaldehyde & 0.462 & 0.249 \\
\hline 74 & $2(1 \mathrm{H})$-naphthalenone & 1.024 & 0.552 \\
\hline 75 & 1-dodecyne & 0.515 & 0.278 \\
\hline 76 & Benzene acetonitrile & 2.488 & 1.341 \\
\hline 77 & Decahydro-4,4,8,9,10-pentamethylnaphthalene neopentylidene cyclohexane & 0.712 & 0.384 \\
\hline 78 & 3-cyclohexane-1-carboxaldehyde & 0 & 0 \\
\hline 79 & Silane & 0.78 & 0.42 \\
\hline 80 & A-phenyl-decahydro-4,4,8,9,10-pentamethylnaphthalene $2(1 \mathrm{H})$-naphthalenone & 0.967 & 0.521 \\
\hline 81 & 3-cyclohexene-1-carboxaldehyde & 0 & 0 \\
\hline 82 & Decahydro-9-ethyl-4,4,8,10-tetramethylnaphthalene neopentylidene cyclohexane cyclopropane & 0 & 0 \\
\hline 83 & Bicycle [2.2.1] heptane & 1.212 & 0.653 \\
\hline 84 & 3,4-bis (1-methylethenyl)-1,1-dimethyl-cyclohexane & 0 & 0 \\
\hline 85 & Diallyldivinylsilane & 1.117 & 0.602 \\
\hline 86 & Neopentylidene cyclohexane naphthalene & 3.009 & 1.622 \\
\hline
\end{tabular}


Citation: Ofodile SE, Boisa N, Obunwo CC, Frank OM (2018) Characterisation of Oil Properties from a Niger Delta Crude. J Environ Anal Toxicol 8: 563. doi:10.4172/2161-0525.1000563

Page 6 of 7

\begin{tabular}{|c|c|c|c|}
\hline 87 & Decahydro-9-ethyl-4,4,8,10-tetramethylnaphthalene & 0 & 0 \\
\hline 88 & p-menth-8(10)-en-9-ol & 0 & 0 \\
\hline 89 & 2-dodecen-1-yl (-) succinic anhydride spiro [cyclobutane-1,3'-[7] oxabicyclo [4.1.0] heptan-2-one & 0.685 & 0.369 \\
\hline 90 & Neopentylidene cyclohexane 3-cyclohexene-1-carboxaldehyde & 2.101 & 1.132 \\
\hline 91 & Cis-2(1H)-naphthalenone & 0.766 & 0.413 \\
\hline 92 & 1,3,4-trimethyl-longifolenaldehyde & 0 & 0 \\
\hline 93 & Cis-3,6-nonadien-5-one & 1.08 & 0.582 \\
\hline 94 & 2,10-dodecadien-1-ol & 1.384 & 0.746 \\
\hline 95 & Bicycle[3.1.0] hexan-2-one & 0 & 0 \\
\hline 96 & 2-dodecen-1-yl(-)succinic anhydride I,3,5-trihydroxy-2,6-dinitrobenzole & 1.379 & 0.743 \\
\hline 97 & 4-hexenoic acid & 1.266 & 0.682 \\
\hline 98 & 2-butanone & 1.445 & 0.779 \\
\hline 99 & 2(1H)-naphthalenone & 0 & 0 \\
\hline 100 & 9-oxabicyclo[6.1.0] nonane & 0 & 0 \\
\hline 101 & 3-methyl-4-(methoxycarbonyl) hexa-2,4-dienoic acid & 1.172 & 0.632 \\
\hline 102 & Acetamide & 0.78 & 0.42 \\
\hline 103 & Cis-1-naphthalenol & 0 & 0 \\
\hline 104 & Cis-6-octenal & 1.161 & 0.626 \\
\hline 105 & 1-(cyclohexylmethyl)-2-ethyl,-cis-cyclopentane & 0.741 & 0.399 \\
\hline 106 & 4-methyl-1-(1-methylethyl)-, $(1 \alpha, 4 \beta, 5 \alpha)$-6-octenal & 0.485 & 0.261 \\
\hline 107 & $\begin{array}{l}\text { N-methyl-N-[4-[4-methoxy-1-hexahydropyridyl]-2-butynyi]-2H-bisoxireno[2,3:8,8a] } \\
\text { b]furan-7(3ah)-one }\end{array}$ & 0.864 & 0.466 \\
\hline 108 & 2-dodecen-1-yl (-) succinic anhydride $1 \mathrm{H}$-indene & 0.834 & 0.45 \\
\hline 109 & 4-methyl-1-(1-methylethyl)-1 $\alpha, 4 \beta, 5 \alpha$-amorphane-B & 0.474 & 0.255 \\
\hline 110 & Oxirane & 0 & 0 \\
\hline 111 & 2-dodecen-1-yl(-) succinic anhydride decahydro-9-ethyl-4,4,8,10-tetramethylnaphthalen cyclopentane & 0.663 & 0.357 \\
\hline 112 & 2-dodecen-1-yl(-) succinic anhydride 3,5-decadiene & 0.523 & 0.282 \\
\hline 113 & 1-(1,5-dimethylhexyl)-4-(4-methylpentyl)-anthracene & 0 & 0 \\
\hline 114 & Octadecane & 1.086 & 0.585 \\
\hline 115 & 3,5-decadiene & 0.799 & 0.431 \\
\hline 116 & $1 \mathrm{H}$-indene & 0 & 0 \\
\hline 117 & D-homoandrostrane & 0 & 0 \\
\hline 118 & 2-buten-1-one & 0.61 & 0.329 \\
\hline 119 & 5-butyl-6-hexyloctahydro-1H-indene & 0.71 & 0.383 \\
\hline 120 & 5-butyl-6-hexyloctahydro-amorphane B & 0 & 0 \\
\hline 121 & 5-butyl-6-hexyloctahydro-picrotoxinin & 0.536 & 0.289 \\
\hline 122 & $2 \mathrm{H}$-Bisoxirano $[2,3: 8,8 \mathrm{a}]$ azuleno $[4,5-\mathrm{b}]$ furan-7(3ah)-one & 2.276 & 1.227 \\
\hline
\end{tabular}




\begin{tabular}{|l|l|l|l|}
\hline 123 & 2,6-dimethyl-6-(4-methyl-3-pentenyl) -damascone & 0.929 & 0.501 \\
\hline 124 & Tricyclo [4.3-0.07.9] nonane & 1.123 & 0.605 \\
\hline 125 & 15-isobutyl-(13-a.h)-isocopalane & 1.318 & 0.71 \\
\hline 126 & 4(1H)-Pteridinone & 2.55 & 1.374 \\
\hline 127 & Cyclodeca[b] furan-2(3H)-one & 1.893 & 1.02 \\
\hline 128 & Sesquirosefuran & 2.331 & 1.256 \\
\hline 129 & Cis-1H-cycloprop[e] azulene & 2.415 & 1.302 \\
\hline 130 & 5a,13a-1H indene & 0.774 & 0.417 \\
\hline 131 & 5-butyl-6-hexyloctahydro-citenamide & 2.137 & 1.152 \\
\hline 132 & 9-cyclohexyltetradecahydro-2H-1,2,3-triazole-4-carboxaldehyde & 3.029 & 1.633 \\
\hline 133 & Isoquinoline & 2.544 & 1.371 \\
\hline 134 & 2-(acetoxylmethyl)-3-(methoxycarbonyl) biphenylene & 0.493 & 0.266 \\
\hline 135 & Anthracene & 0.583 & 0.314 \\
\hline 136 & 3,3-diethoxy-1,1,1,5,5,5-hexamethyl trisiloxane & 0.41 \\
\hline & TOTAL & 185.53 & 0.221 \\
\hline
\end{tabular}

Table 3: Compositional content (components) of the crude oil.

\section{Conclusion}

The investigation showed that, Afiesere crude oil is a heavy one that contains very little amounts of paraffin (saturates) and high level of higher asphaltic components (aromatics, resins and asphaltenes). This crude oil when distilled, due to its physical and chemical properties, the petroleum products can be conveniently used in cold temperature regions and as a non-fire hazard; maintains vapour formation in fuel tanks and can help in the conversion of crude oil to transportation fuel as the concentration level of metals present in the crude is minimal.

\section{References}

1. Okoye IP, Ofodile SE, Chukwu OC (2011) The Effect of Different Solvent Polarity on the Precipitation of Heavy Organics from a crude oil deposit in the Niger Delta. Scienctia Africana 10: 9-15.

2. Speight JG (2001) Handbook of Petroleum analysis. John Wiley \& Sons, pp: 18-23.

3. Charpentier AD, Bergerson JA, MacLean HL (2009) Understanding the Canadian oil sands industry's greenhouse gas emissions. Environmental Research Letters 4: 014005.

4. Onodjake MC, Osuji LC, Bada KK (2017) Thermophysical and bulk properties of bitumen samples from south western Nigeria. NOGIC R\&D Journal.

5. ASTM D4176-04 (2009) Free water and particulate contamination in distillate fuels.

6. ASTM D4052 (2002) Standard Test Method for density and specific gravity of liquids by digital density meter.
7. ASTM D381-04 (2003) Standard Test Method for gum content in fuel by jet evaporation.

8. ASTM D2500-05 (2003) Standard Test Method for cloud point of petroleum products

9. ASTM D97-06. Standard Test Method for pour point of petroleum products.

10. ASTM D92-05a. (2003) Standard Test Method for flash and fire points by Cleveland open cup tester.

11. ASTM D445-06 (2003) Standard Test Method of kinematic viscosity of transparent and opaque liquids.

12. ASTM D323-06 (2003) Standard Test Method for vapour pressure of petroleum products (Reid method).

13. Speight JG (2004) Petroleum asphaltenes part 1: Asphaltenes, resins and the structure of Petroleum oil and gas. Science and Technology 59: 467-477.

14. Dusseault MB (2001) Comparing Venezuelan and Canadian heavy oil and tar sands. InCanadian International Petroleum Conference. Petroleum Society of Canada.

15. Speight JG (2015) Handbook of Petroleum product analysis. Chemical Analysis: A series of monographs on Analytical Chemistry and its applications. John Wiley \& Sons pp: 1-3.

16. ASTM D5134-98 (2003) Standard Test Method for determination of total paraffins, naphthenes and aromatics in crude oil by gas chromatography.

17. Operation /Instruction Manual of $831 \mathrm{KF}$ Coloumeter, metro ohm.

18. Operation/Manual of flash point tester-Stanhope Seta Multiflash COC module.

19. Speight JG (2007) The Chemistry and Technology of petroleum. 4th edn. CRC Press, Boca Raton, FL, USA. 